\title{
Sensory and Microbial Characteristics of Civet Coffee
}

\author{
Murna Muzaifa ${ }^{\#}$, Dian Hasni ${ }^{\#}$, Anshar Patria ${ }^{\#}$, Febriani $^{*}$, Amhar Abubakar $^{\$}$ \\ ${ }^{\#}$ Agricultural Product Technology Department, Syiah Kuala University, Darussalam, Banda Aceh, 23111, Indonesia \\ E-mail: murnamuzaifa@unsyiah.ac.id; hasni_dian@unsyiah.ac.id; ansharpatria@yahoo.com
}

"Chemistry Department, Faculty of Mathematics and Natural Science, Syiah Kuala University, Darussalam, Banda Aceh, 23111, Indonesia E-mail: febriani_tahar@yahoo.com

${ }^{\$}$ Animal Husbandry Department, Faculty of Agriculture, Syiah Kuala University, Darussalam, Banda Aceh, 23111, Indonesia E-mail:amharab@yahoo.com

\begin{abstract}
Civet coffee has been known as the most expensive coffee in the world. Its high prices are mainly contributed by its uncommon production method. Civet coffee is produced from the coffee beans which have been digested by Asian palm civet or Luwak (Paradoxorus hermaprodites). Civet coffee production is very limited due to its processing is merely depends on civet biologic system. Unfortunately, reliable information on civet microbial digestive is still limited. The aim of this research is to evaluate cup (sensory) and microbial quality of wild and caged civet coffee. Samples of wild and caged civet coffee obtained from Bener Meriah District, Aceh, Indonesia. Sensory quality parameters consist of fragrance, aroma, flavour, aftertaste, acidity, body, balance, uniformity, clean cups, sweetness and overall. Microbial quality was done by enumeration of lactic acid bacteria. The results showed that wild and caged civet coffee relatively had similar profile sensory and microbial characteristics. The score cupping of wild civet coffee is slightly higher than caged civet coffee. Aroma and flavour characteristics of wild and caged civet coffee were herby, nutty, grassy tobacco-like, fishy and sweet but there were over fruity-papaya and guava-like aroma and flavour of caged civet coffee. The lactic acid bacteria count on wild and caged civet were $5.8 \times 10^{8} \mathrm{cfu} / \mathrm{ml}$ and $3,8 \times 10^{8} \mathrm{cfu} / \mathrm{ml}$. Three different colonies from MRS media were isolated and submitted to gram and catalase test. All isolates showed gram-positive and catalase negative. The result confirmed that most colonies are lactic acid bacteria group. Two isolates (ICF 1 and ICF 3) showed proteolytic activity, and isolated ICF 1 showed the largest zone of clearance of $15 \mathbf{~ m m}$. Further investigation is required for identification and selection of performance lactic acid bacteria for artificial civet coffee fermentation.
\end{abstract}

Keywords — coffee; cupping quality; lactic acid bacteria; wild civet; Gayo

\section{INTRODUCTION}

Coffee is globally known as a refreshing beverage which is traded and consumed internationally. The terms of coffee refer to the plant, seeds and the drinkable brewed liquid. The coffee plants have been grown over 80 centuries in tropic and sub-tropic regions and consider as the ultimate trade commodity after petroleum.

Coffee is consumed because of its typical aroma and flavor. The brewed liquid of coffee is always pleasing and stimulating, and hence become the favorite of many people. Many researchers reported that a pleasant sensation, an equilibrium mixture of flavor, body and the non-presence of taints and faults are a fine description of good quality coffee flavour [1], [2].

Sensory analysis is a very important tool for the characterization of different types of coffee. Sensory evaluation in coffee industries is known as cupping. Sensory properties of coffee have been a target for research for over a century. The sensory properties measured through a sensory evaluation involving humans as the receptors [2], [3].

One of the methods for sensory evaluation that has been emphasized for evaluating the quality of specialty coffee is the Specialty Coffee Association of America (SCAA) method. This method based on quantitative and descriptive sensory analysis of the beverage, which is performed by a team consists of selected and trained judges. According to this methodology, coffee beans are scored from 0 to 10 points in the evaluation of primary attributes that comprise the sensory profile of coffee: fragrance/aroma, clean cup, uniformity, sweetness, flavour, body, acidity, aftertaste, balance and overall impression of the coffee. The total amounts of examined attributes entitle as the final score, which defines as the overall coffee quality. Specialty coffee is named for coffee which holds final score higher than 80 points [4].

Some researchers argue that coffee quality which is measured by its aroma and flavour, as well as hedonic tests 
might be subjective. This point of view comes out as an impact of panellist bias and varied sensitivity. However, there is also vice versa perspective, which considered coffee sensory quality as important factors on coffee quality. Nowadays many studies focus on to establish logical explanation between roughly 800 chemical compounds and its function as aroma precursor of roasted coffee. The results stated that coffee post-harvest and processing techniques are significantly involved which led the researchers to peel-out the processing methods as determinant factors of coffee quality [5], [6], [7].

In coffee bean processing, some processing techniques are applied to the harvested coffee fruits to green bean. The techniques are dry processing (natural), wet processing (washed) and semi-dry processing (semi-washed). The differences in processing can impact coffee flavour [8], [9]. There are certain 'specialty' styles of coffee that are produced using uncommon processing methods such as a' digestive bio-processing.' The coffee processing by fermentation inside the intestine of civet (kopi luwak in Indonesia ) and elephant (Aanee Kaapi in India) [2], [10], [11].

Civet coffee is one of the most popular coffee. It has been produced from the coffee beans which have been digested by a certain Indonesia cat-like animal, Asian palm civet (Paradoxorus hermaproditus) or Luwak (Fig. 1). The main region producer kopi luwak is Indonesia. Civet coffee also find in various locations in Ethiopia[10].

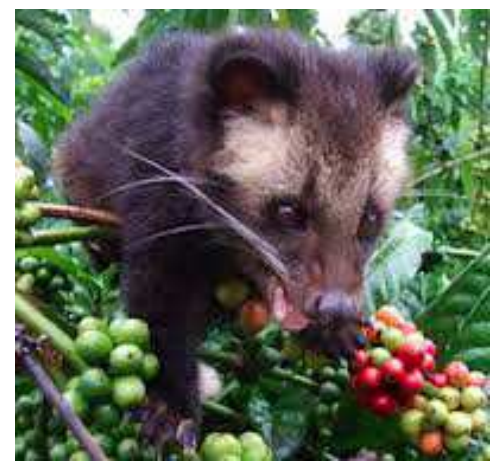

Fig. 1 Asian palm civet (Paradoxorus hermaproditus)

Asian palm civet is native to regions within and around Asia. They naturally live in temperate and tropical forests. But in developed areas, they also found in parks, suburban gardens, plantations and fruit orchards. Where these civets choose to live depends mostly on availability of food and the presence of areas they can rest in [12].

The processing of civet coffee is unusual, civet selects and eats the coffee berries based on its animal instinct. During the digestion process on intestinal civet, coffee beans are not digested by the civet. The beans hence excrete with civet dropping. Farmer collected the dropping, washed and dried [13].

Civet coffee is very hard to find. It is estimated about $250-500 \mathrm{~kg}$ per year of civet coffee come from wild civet coffee. Since the civet coffee is rare and unique, as well as has high economic value, the farming methods of civet coffee were introduced and bloomed in this past years. It is estimated about 50 tons of caged civet coffee is produced on-farm annually [13], [14].
Civet coffee is claimed as the most expensive coffee in the world. The price for a single cup of civet coffee runs $\$ 35-\$ 80$, and one pound bag of beans costs $\$ 100$ to $\$ 600$. Other expensive coffee is Jamaica Blue Mountain Coffee that produced in the Blue Mountain region of Jamaica. It's price reaches up to $\$ 40$ a pound [15].

The study on sensory quality of wild and caged civet coffee is still limited. Coffee bean that was fermented naturally in the gastrointestinal tract of civet changed the chemical composition of coffee bean and gave specific taste and odour of coffee due to the enzymatic process and bacteria found in the gastrointestinal tract of this civet [10]. The coffee fermentation is characterized by a presence of different microorganisms. It should be possible to produce artificial civet coffee through controlled fermentation using indigenous civet microorganism as the culture starter. Unfortunately, scientific information on microbial digestive of civet is still limited.

Lactic acid bacteria is one of the common bacteria found in the gastrointestinal tract. It's well known that lactic acid bacteria is the most important bacteria used as starter cultures in fermentation. By doing so, several aspects named as safety, technological effectiveness and economics, and economics and others specific standards have to be fulfilled when selecting strains as starter cultures in food fermentation. Specifically said, lactic acid bacteria are selected based on the type and the desired specification outcome, the intended metabolic activities, the characteristic of raw materials as well as the applied technology. This research aims to evaluate sensory and microbial characteristics of wild and caged civet coffee.

\section{MATERIAL AND METHOD}

\section{A. Materials}

The research was an explorative study on determined quality of wild and caged civet coffee. The research was conducted in Bener Meriah District, part of Gayo Highland, Aceh Indonesia. Materials used were wild and caged civet coffee. Wild civet coffee obtained from the collector in Blang Panas, while caged civet coffee obtained from a farmer in Pondok Baru, Bener Meriah district, Aceh Indonesia.

\section{B. Civet Feces Collection}

Fresh (wet) civet feces of wild and caged Luwak were collected in sterilized sampling flask and was brought to Microbiology Laboratory with ice box. The samples were kept in the cooler at $4^{\circ} \mathrm{C}$ until the experiment was conducted. In terms of sensory evaluation, wet and dried feces from wild and caged civet are collected up to $2 \mathrm{~kg}$, washed, sundried up to moisture content about $12 \%$. The husk that is still surrounded the bean removed manually, the green bean than packaged and stored.

\section{Enumeration of Microorganism Population}

The microorganism was isolated from civet feces by taking one loop of the feces samples into peptone solution and shakes for another 15 minutes on the shaker. $1 \mathrm{ml}$ of sample was mixed to $9 \mathrm{ml}$ of sterile distilled water then it was continuously diluted. Then about $0.1 \mathrm{ml}$ of each dilution 
was randomly spread onto sterile MRS agar (Man Rogosa and Sharpe, Merck Germany). The plate instantly was incubated at $37^{\circ} \mathrm{C}$ for the next 24 hours. The culture then was enumerated in Petri dishes started from 30 to $300 \mathrm{cfu}$. The enumeration was done three times, and the average value represents lactic acid bacteria in cfu (colony forming unit) per millilitre of the sample [16].

\section{Characterization of Lactic Acid Bacteria}

Different and single colony types from MRS media were picked up and purified by repeated streaking. Pure cultures were submitted to gram and catalase test to confirm as lactic acid bacteria. The ones that had Gram-positive and catalase negative selected, the sub-cultured onto slants media and maintained for screening. Selected isolates from samples were spot inoculated on $1 \%$ skim milk agar plates and incubated at $37^{\circ} \mathrm{C}$ for 24 hours. The formation of clear zone (halo) around the colonies indicated the proteolytic activities of bacteria resulting from milk protein hydrolysis. The diameter of halo formation was measured in $\mathrm{mm}$ [17].

\section{E. Sample Preparation for Sensory Evaluation}

The green bean roasted with 65 Agtron scales and ground up to 20 mesh. The samples (green bean) should be ground immediately prior to cupping, no more than 15 minutes before infusion with water [18].

\section{F. Sensory (Cupping) Evaluation}

The sensory quality (cupping quality) was performed by a group of three certified judges who operate commercially in various coffee-producing regions in Gayo Highland (Gayo Cuppers Team). The judges are intensively trained over a week before certified as Q-grader by Coffee Quality Institute-United States, as an official international body which is eligible to conduct this panellist selection. To be valid, the judge eligibility as coffee grader is calibrated over three years.

As the Quantitative Descriptive Analysis (QDA), Gayo Cuppers Team has sample standard which is regularly examined by the judges. The sample standard is regular Gayo Arabica coffee, which is semi-wash processed. Therefore the judges are well-acknowledged with characteristics of Gayo Arabica coffee. The analysis ran down based on Specialty Coffee Association of America (SCAA) method [18]. Ten attributes of cupping analysed were fragrance/aroma, clean cup, uniformity, sweetness, flavour, body, acidity, aftertaste, sweetness, balance and overall impression of the coffee. The steps of the procedure of cupping evaluation were:

1) Fragrance/Aroma: The dry fragrance should be examined during the first 15 minutes. Fragrance score is obtained by lifting the lid to sniff the coffee powder. Then aroma is valued by infusing the coffee grounds with water, the appeared crusts on the surface left unbroken for approximately 3-5 minutes. Then the beverage is stirred 3 times to broke out the crust. Sniffing the aroma is done with spooning the liquor with the back of the spoon which allows the foam to run down the cup. The score for fragrance is then marked by dry grounds evaluation whilst the aroma of the liquid drinks. The score is listed in the questionnaire.
2) Flavor, Aftertaste, Acidity, Body, and Balance: Flavour, aftertaste, acidity, body, and balance are evaluated when the coffee liquor temperature reached to $160 \mathrm{oF}(71 \mathrm{oC})$ which is commonly occurred roughly $8-10$ minutes from the infusion. The process starts by aspirating the liquor into the mouth in a special way in order to the liquor covers the palatable area as large as possible, especially the tongue and upper palate. By doing so, the retronasal vapors are at its maximum intensity at these elevated temperatures, where flavor and aftertaste are marked at this point. Then as the liquor temperature decreases $\left(160^{\circ}-140^{\circ} \mathrm{F}\right)$, acidity, body, and balance are followed. The cuppers assess balance as for how well the mixture combination of flavor, aftertaste, acidity, and body in a way to produce synergistic combination.

3) Sweetness, Uniformity, and Cleanliness: Sweetness, uniformity, and cleanliness are evaluated in order as the coffee liquor reaches room temperature (below $100^{\circ} \mathrm{F}$ ) and should be over when the temperature of the sample down to $70^{\circ} \mathrm{F}\left(21^{\circ} \mathrm{C}\right)$. For this evaluation, one sample is placed in five different cups. Then each coffee grader should examine on each individual cup, the maximum marks for each cup are 2 points (total 10 points for each sample).

4) Overall and Defects: Overall refers to the holistic reflection of integrated rating of samples as perceived by the coffee grader. The overall score is given after the coffee grader assessed all attributes and combined these as "cupper's points". As similar as sweetness, uniformity, and cleanliness, overall is measured by awarding 2 points per cup where coffee grader has assessed 5 cups or each coffee samples in order to reach 10 points maximum scores. Defects refer to negative or poor flavors which detect during cupping test. Defects divided into two categories, which is taint and fault. Taint is score -2 , which meant that this score is given to sample which has off-flavor, but not overwhelming. Taint commonly notice in aromatic aspects. Another one is the fault, as an off-flavor which cause unpalatable. This defects mostly found in taste aspects, since it affects all cupping attributes, the score is -4 .

5) Final Score: When the evaluation is over, all the scores are marked on the cupping form [18]. The final score is based on the flavor experience of the individual assessor as single judges. These are rated on 16-point scale quality in quarter-point increments between numeric values from 6 to 9. These levels are shown in Table 1.

TABLE I

LEVELS OF QuALITY BETWEEN NuMERIC VALUES

\begin{tabular}{|l|l|l|l|}
\hline \multicolumn{4}{|c|}{ Quality scale } \\
\hline $\begin{array}{l}6.00- \\
\text { Good }\end{array}$ & $\begin{array}{l}7.00- \\
\text { Very Good }\end{array}$ & $\begin{array}{l}8.00- \\
\text { Excellent }\end{array}$ & $\begin{array}{l}9.00- \\
\text { Outstanding }\end{array}$ \\
\hline 6.25 & 7.25 & 8.25 & 9.25 \\
\hline 6.5 & 7.5 & 8.5 & 9.5 \\
\hline 6.75 & 7.75 & 8.75 & 9.75 \\
\hline
\end{tabular}

The sum of the individual score of all attributes constitutes the total scores. Then total scores should be subtracted from defects in order to have final scores. Final 
score represents the overall quality of the coffee. Scoring key has proven to be a meaningful way to describe the range of coffee quality for the final score as shown in Table 2 .

TABLE III

RANGE OF COFFEE QUALITY FOR FINAL SCORE

\begin{tabular}{|l|l|l|}
\hline \multicolumn{3}{|c|}{ Total Score Quality Classification } \\
\hline $90-100$ & Outstanding & \multirow{2}{*}{ Specialty } \\
\hline $85-89.99$ & Excellent & \\
\hline $80-84.99$ & Very Good & Not Specialty \\
\hline$>80.0$ & Below Specialty Quality &
\end{tabular}

Source: SCAA (2009)

\section{G. Data Analysis}

All data obtained from the sensory analysis represented in graphic and table form. Data then statistically analysed with paired t-test with Microsoft Excell ver. 2010. The null hypotheses are there is no difference exists in the wild and caged civet coffee.

\section{RESULTS AND DISCUSSION}

\section{A. Sensory Characteristics}

Sensory analysis of wild and caged civet coffee conducted by cupping test. The cupping profile of wild and caged civet coffee is shown in Table 3.

TABLE IIIII

SENSORY ATTRIBUTES OF CIVET COFFEE SAMPLES

\begin{tabular}{|l|rl|rl|}
\hline Attributes & \multicolumn{2}{|c|}{ Wild Civet Coffee } & \multicolumn{2}{c|}{ Caged Civet Coffee } \\
\hline Fragrance /Aroma & 8.00 & \pm 0.00 & 7.75 & \pm 0.25 \\
\hline Flavour & 8.00 & \pm 0.00 & 8.00 & \pm 0.00 \\
\hline Aftertaste & 7.92 & \pm 0.14 & 7.75 & \pm 0.25 \\
\hline Acidity & 7.50 & \pm 0.00 & 7.25 & \pm 0.25 \\
\hline Body & 7.83 & \pm 0.29 & 8.00 & \pm 0.00 \\
\hline Balance & 7.75 & \pm 0.25 & 8.00 & \pm 0.00 \\
\hline Uniformity & 9.33 & \pm 1.15 & 10.00 & \pm 0.00 \\
\hline Cleancups & 10.00 & \pm 0.00 & 10.00 & \pm 0.00 \\
\hline Sweetness & 10.00 & \pm 0.00 & 10.00 & \pm 0.00 \\
\hline Overall & 8.00 & \pm 0.00 & 8.00 & \pm 0.00 \\
\hline
\end{tabular}

Table 3 showed that the profile of cupping quality of wild and caged civet coffee is slightly different value. Wild civet coffee has a slightly higher score in terms of fragrance/aroma and acidity whilst caged civet coffee is more superior on balance. In coffee quality, terms of fragrance refer to the aromatic evaluation of dry coffee grounds whereas aroma represents aroma coffee liquor. The mechanism of coffee aroma formation is very complex. Aroma is made up the complex mixture of volatile compounds such as sulphur compounds, pyrazines, pyridines, pyrazoles, oxazole, furans aldehydes, ketones and phenols formed during the roasting process [19], [20]. A number of chemical reactions during roasting are Maillard reactions, Strecker degradation, caramelization and oxidation [20], [21]. During roasting, sucrose is inverted through Maillard reactions and caramelization process. Superior aroma and flavour of coffee are highly influenced by its carbohydrate contents [22].
In present study shows that acidity of civet coffee is slightly higher than the caged one. Acidity defines as a bright and dry sensation that elevates the saliva and coffee taste. The absence of acidity led the dullness and flat coffee taste. Acidity is not similar with sour, which classifies as defects, nor should it be too dry or astringency. The best condition of acidity described as sweet and tart vibrant that lifts pleasurable feeling of drinking the coffee liquor. It gives delicate and crispy sensation, lush and rich and another way to describe.

While the volatile compounds largely account for the aromatic properties, the non-volatile compounds are responsible for coffee acidity [23]. Some researchers have indicated that the acidity of coffee is due to organic acids (phosphoric acid, chlorogenic acid, quinic acid and aliphatic acids) present in the roasted coffee [24], [25]. Moreover, chlorogenic acids also reported as influencing agents of astringency and bitterness to the coffee brew. As high its contents of chlorogenic acids in green coffee may produce undesirable flavor which likely due to oxidation process former to roasting process [26]. Therefore, the further research is required to explain this mechanism in civet coffee clearly.

The other sensory attributes that are studied here, flavor, aftertaste, body, uniformity, clean cup, sweetness and overall for both of wild and caged civet coffee are similar. Arabica coffee from Gayo Highland which is a full wash or semi wash processed is reported to have the low body and high score of cleanliness, sweetness and overall. This pattern commonly mapped during cupping tests of Gayo coffee, which leads to specific characteristics Gayo coffee [27]. However, the statistical report as can be seen in Table IV states that there is no difference exists for both samples, as the null hypotheses are accepted as T-value (0.48) is lower that p-value 0.05 for both one (1.83) and two tail (2.26).

TABLE IVV

PAIRED T-TEST RESUlTS

\begin{tabular}{|l|r|r|}
\hline & \multicolumn{1}{|c|}{$\begin{array}{l}\text { Wild Civet } \\
\text { Coffee }\end{array}$} & Caged Civet Coffee \\
\hline Mean & 8.433333333 & 8.475 \\
\hline Variance & 0.916358025 & 1.159027778 \\
\hline Observations & 10 & 10 \\
\hline $\begin{array}{l}\text { Pearson } \\
\text { Correlation }\end{array}$ & 0.970781518 & \\
\hline $\begin{array}{l}\text { Degree of } \\
\text { Freedom }\end{array}$ & 9 & \\
\hline t Stat & -0.482867085 & \\
\hline $\mathrm{P}(\mathrm{T}<=\mathrm{t})$ one-tail & 0.320359319 & \\
\hline $\mathrm{t}$ Critical one-tail & 1.833112933 & \\
\hline $\mathrm{P}(\mathrm{T}<=\mathrm{t})$ two-tail & 0.640718638 & \\
\hline $\mathrm{t}$ Critical two-tail & 2.262157163 & \\
\hline
\end{tabular}

TABLE V

CUPPING SCore OF WiLd AND CAGEd Civet Coffee

\begin{tabular}{|c|c|c|}
\hline \multirow{2}{*}{ Attribute } & \multicolumn{2}{|c|}{ Cupping Score } \\
\cline { 2 - 3 } & Wild civet coffee & Caged civet coffee \\
\hline Total score & $85,00 \pm 0.25$ & $84,75 \pm 0.25$ \\
\hline Defects & 0,00 & 0,00 \\
\hline Final score & $\mathbf{8 5 , 0 0} \pm 0.25$ & $\mathbf{8 4 , 7 5} \pm 0.25$ \\
\hline
\end{tabular}


The sum of the individual score of all attributes constitutes the final scores, which represents the overall quality of the coffee as shown in Table 5. According to Table 5, cupping score of wild civet coffee is slightly higher from caged coffee. Wild civet coffee scored 85, and caged civet coffee 84.75 , both of this coffee fulfilled the coffee specialty standard. For coffee that higher than 80 points are counted as specialty coffee [4]. According to scoring key [18], civet coffee classified as excellent specialty while caged civet coffee is classified as a very good specialty.

TABLE VI

AROMA AND FlAVOR DESCRIPTION OF CIVET COFFEE

\begin{tabular}{|c|c|}
\hline \multicolumn{2}{|c|}{ Description aroma and flavor of civet coffee } \\
\hline Wild civet coffee & Caged civet coffee \\
\hline Nutty & Nutty \\
\hline Creamy & Mint \\
\hline Herby & Bitter \\
\hline Mint & Balance \\
\hline Grassy-tobacco like & Grassy-tobacco like \\
\hline Fishy & Fishy \\
\hline Sweet & Sweet \\
\hline Good body & Good body \\
\hline Light acidity & Light acidity \\
\hline & Over fruit papaya and \\
& guava-like \\
\hline
\end{tabular}

Table 6 showed that aroma and flavor description of wild civet coffee are nutty, creamy, herby, mint, grassy-tobacco like, fishy, sweet, good body and light acidity. Aroma and flavor description of caged civet coffee are nutty, mint, bitter, balance, grassy-tobacco like, fishy, sweet, good body, light acidity, over fruit papaya and guava-like. According to [25], wild civet coffee has a strong aroma, flavor and aftertaste, good balance but sometimes accompanied by the earthy aroma. The type of food eaten by civet affect the aroma of civet coffee. the wild civet eats many kinds of food in the forest while for caged civet, fruits are more given as feeding pattern. Papaya and guava are the most often given fruits for this caged civet, interestingly the fruit aroma appears on coffee produced. The relationship between flavor precursor and the sensory properties presented in the complex coffee matrix should be fully understood. Next, chemical analysis data would be required for identification of chemical compositions and cupping attributes correlation that might impact overall civet coffee quality. Flavor should be linked with its taste, several researchers have been made to predict the coffee sensory profile by instrumental measurement results [29], [30] and [31]. Therefore a novel approach of data standardization schemes is proposed to relate the chemical compounds and its sensory properties. The knowledge of the chemistry compounds (volatile compositions) would facilitate a better understanding of coffee quality [2], [31], [33]. The ultimate target in this coffee genetic program is an improvement the quality attributes. Advances in genomics are providing new tools for analysis of coffee at the molecular level. The aims are to identify the responsible genes for controlling the major biochemical components which are important in determining coffee quality [34].

\section{B. Microbial Characteristics}

Civet feces are the excretion of the civet digestive system. Normally civet feces are semisolid with the mucus coating. The appearances are varied significantly (i.e., form, size, colour, texture) according to the state of civet's taken diet, as can be seen in Fig. 2.

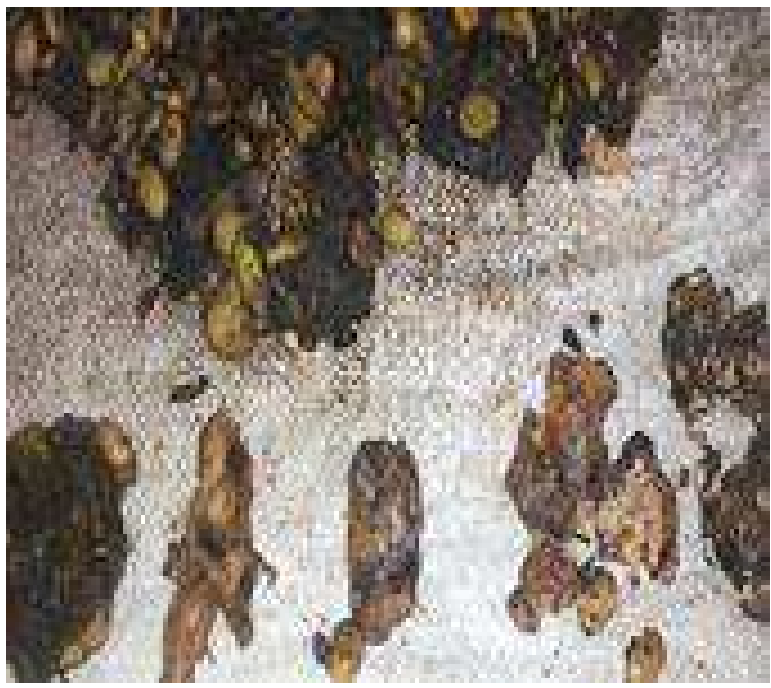

Fig. 2 Appearance of civet feces

Civet feces found in coffee plantations often contains coffee bean, seeds of other fruits and part of insects. The civet feces used in this study were fresh and intact, so that still contain original bacteria. Lactic acid bacteria is one of the common bacteria found in the gastrointestinal tract. Lactic acid bacteria count of civet feces was reported in Table 7.

TABLE VII

LACTIC ACID BACTERIA COUNT ON CIVET FECES

\begin{tabular}{|c|c|}
\hline Sample & Colony count $(\mathbf{c f u} / \mathbf{m l})$ \\
\hline Wild civet coffee & $5,8 \times 10^{8}$ \\
\hline Caged civet coffee & $7,9 \times 10^{8}$ \\
\hline Average & $6,8 \times 10^{8}$ \\
\hline
\end{tabular}

There were the different number of lactic acid bacteria obtained from the feces of wild and caged civet. This differences could be affected by the life condition and the diet taken by the civet. Lactic acid bacteria are part of the normal microorganism, the ecosystem that naturally inhabits the gastrointestinal and genitourinary tracts, which comprised of a large number of different bacterial species with the diverse amount of strains [35], [36].

Lactic acid counted bacteria on this study were $5.8 \times 10^{8}$ $\mathrm{cfu} / \mathrm{ml}$ and $7.9 \times 10^{8} \mathrm{cfu} / \mathrm{ml}$. This is slightly higher than lactic acid bacteria count enumerated by previous research, $3.0 \times 10^{8} \mathrm{cfu} / \mathrm{ml}$ [37]. The count of lactic acid bacteria showed that lactic acid bacteria found on gastrointestinal tract of civet and may play a role in civet coffee fermentation. This is common knowledge that lactic acid bacteria is one of the most important bacteria used as starter cultures in fermentation. However, numerous specific aspects have to be considered when selecting the strain for the starter culture. Therefore the LAB selection procedures will be based on the type and the desired characteristics of the final 
product, the desired metabolic activities, raw material and matched technology applied.

The first step of the characterization of lactic acid bacteria from civet feces was the isolation of the bacteria on MRS agar media. Based on the morphological colony, three different colonies were isolated from the media. The colony characteristic of isolates showed in Table 8.

TABLE VIII

COLONY CHARACTERISTICS OF ISOLATES

\begin{tabular}{|c|c|c|c|l|c|}
\hline \multirow{2}{*}{ No } & \multirow{2}{*}{$\begin{array}{c}\text { Isolat } \\
\text { es }\end{array}$} & $\begin{array}{l}\text { Patern } \\
\text { Form }\end{array}$ & Elevation & Colour & $\begin{array}{c}\text { Size } \\
\text { (mm) }\end{array}$ \\
\cline { 3 - 6 } 1 & ICF 1 & circular & raised & $\begin{array}{l}\text { milky } \\
\text { white }\end{array}$ & 1,0 \\
\hline 2 & ICF 2 & circular & raised & $\begin{array}{l}\text { light } \\
\text { milky } \\
\text { white }\end{array}$ & 1,0 \\
\hline 3 & ICF 3 & circular & raised & $\begin{array}{l}\text { milky } \\
\text { white }\end{array}$ & 2,0 \\
\hline
\end{tabular}

The isolates were submitted to Gram stain and catalase test. The result showed that all of the isolates were Grampositive and catalase negative. It confirmed that they are lactic acid bacteria (Table 9). The Gram stain has been used for a long time to classify bacteria according to the chemistry of their cell walls. Gram-positive bacteria coloured the crystal violet stain to be purpled when seen under the microscope. This is due to the thick layers of peptidoglycan in the bacterial cell wall keep the stain after it washed away, in the decolourization stage of the test. The cell wall is complex assembly polymers and proteins. The peptidoglycan sacs which circle the cytoplasmic membrane, which is decorated with teichoic acid, polysaccharides, and proteins. It plays a major role in bacterial role in bacterial physiology since it maintains cell shape and integrity during the cell development. It also plays as the interface between the bacterium and its environment [38]. Lactic acid bacteria lack catalase, they possess superoxide dismutase and have alternative means to detoxify peroxide radicals, generally through peroxidase enzymes [39].

TABLE IX

CELl CHARACTERISTICS OF ISOLATES

\begin{tabular}{|c|c|c|c|c|}
\hline No. & $\begin{array}{c}\text { Isolate } \\
\text { s }\end{array}$ & Cell form & Gram staining & Catalase \\
\hline 1 & ICF 1 & Cocci & + & - \\
\hline 2 & ICF 2 & Rods & + & - \\
\hline 3 & ICF 3 & Cocci & + & - \\
\hline
\end{tabular}

All isolates were evaluated for their potentiality to produce protease. Isolation of proteolytic lactic acid bacteria was carried out using MRS agar media and further screened for protease production on skim milk agar plates. Results of screening protease production showed that two isolates (ICF 1 and ICF 2) able to produce protease (Table 10).

Isolate ICF 1 showed the maximum clearance area with diameter $15 \mathrm{~mm}$. Formation of clear zones around the colonies was considered as an indication of protease production (Fig. 3).
TABLE X

SCREENING OF PROTEOLYTIC LACTIC ACID BACTERIA

\begin{tabular}{|c|c|c|c|}
\hline No & Isolates & $\begin{array}{c}\text { Detection of } \\
\text { Proteolytic }\end{array}$ & $\begin{array}{c}\text { Clear zone } \\
\text { (mm) }\end{array}$ \\
\hline 1 & ICF 1 & + & 15 \\
\hline 2 & ICF 2 & - & - \\
\hline 3 & ICF 3 & + & 10 \\
\hline
\end{tabular}

$+:$ presence of clear zone around colony

- : absence of clear zone around colony

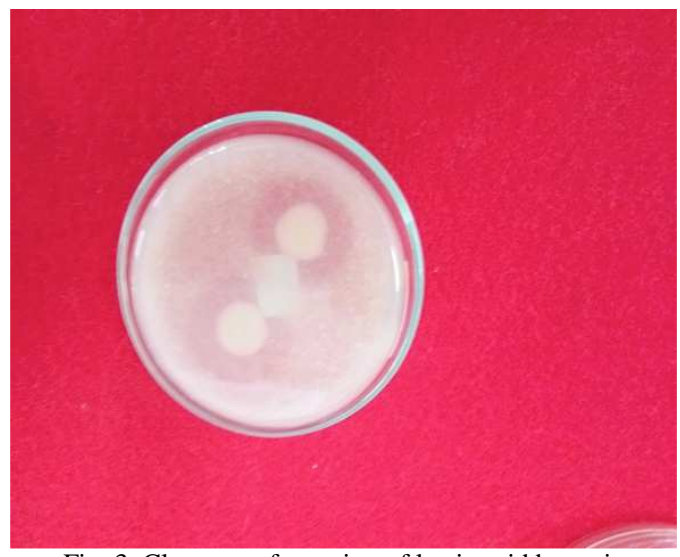

Fig. 3 Clear zone formation of lactic acid bacteria

Bacterial proteases are generally used to break down oligopeptides into amino acids. That was one of the important criteria of a lactic acid bacteria isolates could be used as a starter. Lactic acid bacteria is best known as starter culture due to their versatile metabolic characteristics such as acidification activity, proteolythic activity and synthesis of its metabolites [40]. The proteolytic system of lactic acid bacteria is contributing to flavor development in fermented products. The next step in this research is to identify of the protolithic lactic acid bacteria by molecular assessment and to analyse the lactic acid bacteria performance as a starter on coffee fermentation (artificial civet coffee fermentation).

\section{CONCLUSIONS}

Based on t-test analysis, cup quality of wild and caged civet coffee from Bener Meriah, Aceh Indonesia is similar. However wild civet coffee had slightly higher cupping score quality than caged civet coffee, and both of this civet coffee met the requirements of specialty coffee. Aroma and flavour characteristics of wild and caged civet coffee were similar relatively (herby, nutty, grassy tobacco-like, fishy and sweet) but there were over fruity papaya and guava-like aroma and flavour on caged civet coffee. Lactic acid count bacteria on wild and caged civet coffee were $5.8 \times 10^{8} \mathrm{cfu} / \mathrm{ml}$ and $3.8 \mathrm{x}$ $10^{8} \mathrm{cfu} / \mathrm{ml}$. The isolates of lactic acid bacteria from the civet feces showed proteolithic activity. Analysis of lactic acid bacteria performance as a starter on coffee fermentation and identification of the strain would be done. Chemical analysis data would be required for identification of chemical compositions and cupping attributes correlation that might impact overall civet coffee quality. 


\section{ACKNOWLEDGMENT}

We would like to thank Syiah Kuala University and Ministry of Research, Technology and Higher Education for supporting this research through Fundamental Research Grant 2016.

\section{REFERENCES}

[1] E.E. M. Mori, M. Bragagnolo, M.A. Morgano, V.D.A. Anjos, K. Yotsuyanagi, E.V. Faria, J.M. Iyomasa, "Brazil coffee growing regions and quality of natural, pulped natural and washed coffees", Food and Food Ingredients Journal of Japan, vol 208, pp 416-423. 2003.

[2] W.B. Sunarharum, D.J. Williams, H.E Smith, "Complexity of coffee flavor: A compositional and sensory perspective", Food Res. Int, vol 62, pp 315-325. 2014.

[3] F.M. Borem, F.C Ribeiro, L.P Figueiredo, G.S. Giomo, V.A Fortunato and E.P Isquierdo, "Evaluation of the sensory and color quality of coffee beans stored in hermetic packaging", J. Stored Prod. Res vol 52, pp 1-6. 2013.

[4] T.R. Lingle. The Coffee Cuppers Hand Book. California: Long Beach. 2001.

[5] A, Farah, M.C. Monteiro, V. Calado, A. Franca , L.C. Trugo, “ Correlation between cup quality and chemical attributes of Brazilian coffee", Food Chem. Vol 98, pp 373-380. 2006

[6] G. Bytop, D. Selmar and P. Schieberle, "New aspects of coffee processing: how do the different post harvest treatments influence the formation of potential flavor precursors", J. Appl. Bot. Vol 74, pp 131-136. 2000.

[7] S.E. Knopp, G. Bytof, D.Selmar, "Influence of processing on the content of sugars in green Arabica coffee beans", European Food Research and Technology, vol 223, pp 195-201. 2006.

[8] R.J. Clarke and R. Macrae, Coffee Vol.1, Chemistry, New York: Elsevier 1985.

[9] S.C. Duarte, A. Pena, C.M. Lini, "A review on ochratoxin A occurrence and effects of processing of cereal and cereal derived food products", Food Microbol, vol 27, pp 187-198. 2010.

[10] M. F. Marcone, "Composition and properties of Indonesian palm civet coffee (Civet coffee) and Ethiopian civet coffee."Food Research International, vol 37, pp 901-912. 2004.

[11] C. Kushalappa, C. Garcia, Y. Raghuramulu, K.M. Nanaya," Elephants also like coffee: coffee and environmental services in the western Ghats of India", Poster in Multi-starata agroforestry systems with perennial crops: making ecosytems services count for farmers, consumers and the environment. CATIE, Turrialba, Costa Rica, 2007.

[12] R.M. Nowak, Walker's Mammals of the World, London \& Baltimore : The John Hopkins University Press, 1999.

[13] M. Cuang-Hoang, "Method for processing coffee and coffee processed by this method", Patent WO 2012009730A1, Jan 19, 2012

[14] U. Jumhawan, , S.T. Putri, Yusianto, E. Marwani, T. Bamba, E. Fukusaki, "Selection of discriminant markers for authentication of asian palm civet coffee (civet coffee): A Metabolomics Approach", Journal of Agricultural and Food Biochemistry, vol 6, pp 7994-8001. 2013.

[15] (2015) Most expensive.coffee website. [Online]. Available: http:// http://www.most-expensive.coffee/

[16] M. Mirlohi, S. Soleimanian-Zad, M. Sheikh-Zeiondin, H. Fazeli, " Enumeration of lactobacilli in the fecal flora of infant using two different modified de-man rogosa sharpe media under aerobic and anaerobic incubation", Pakistan Journal of Biological Science, vol 11(6), pp 876-81. 2008.

[17] A.B Vermelho, M.N.L Meirelles, A. Lopes, S.D.G Petinate, A.A Chaia, M.H Branquinha, "Detection of extracellular proteases from microorganisms on agar plates", Mem Inst Oswaldo Cruz, vol 91 pp 755-760. 1996

[18] (2009). SCAA website. [Online]. Available: http://www.scaa.org/.
[19] R.A. Buffo and C. Cardelli-Perreira, "Coffee flavor: an overview," Flavor and Fragrance Journal, vol 19, pp 99-104. 2004.

[20] A.T.Toci and Farah,"Volatile compounds as potensial defective coffee beans' markers,"Food Chem, vol 108, pp 1133-114. 2008.

[21] W. Holscher and H. Steinhart, Aroma compounds in green coffee ed G. Charalambous.. In Food Flavors: Generation, Analysis and Process Influence. Amsterdam; Elsevier Science, 1995.

[22] Flament, I. and Y. Bessiere-Thomas. Coffee Flavor Chemistry. John Wiley and Sons Ltd, Baffins Lane, Chichester, West Susex. 2002.

[23] I.D. Fisk, A. Kettle, S. Hofmeister, A. Virdie, J. Silanes Kenny, "Discrimination of roast and ground coffee aroma", Flavor, vol 1 (14). 2012

[24] F.C. Ribeiro, F.M. Borem, G.S Giomo, R.R. Lima, M.R. Malta and L.P Figueredo, "Storage of green coffee in hermetic packaging injected with CO2, "Journal of Stored Products Research, vol 47, pp 341-348. 2011.

[25] E.K. Bekedam, H.A. schools, M. Van Boekel and G. Smith, "High molecular weight melanoidins from coffee brew. Journal of Agricultural and Food Chemistry", Journal of Agricultural and Food Chemistry, vol 54, pp 7658-766. 2006.

[26] A. Farah. Coffee Constituents. In "Coffee: Emerging Health and Disease Prevention". $1^{\text {st }}$ Edition. John Wiley \& Sons. Blackwell Publishing. 2012.

[27] R. Hulupi, D. Nugroho and Yusianto. "Performance of some Arabica Coffee local varieties from Gayo Highland. Pelita Perkebunan Vol. 29 No. 2. Pp. 69-81. 2013.

[28] Yusianto, "Pengolahan dan komposisi kimia biji kopi dan pengaruhnya terhadap cita rasa seduhan", Warta Pusat Penelitian Kopi dan Kakao, vol 15, pp 90-202. 1999.

[29] E. Varvolgyi, A. Gere, D. Szollosi, L. Sipos, Z. Kovacks, Z. Kokai, M. Csoka, Zs. Mednyanszky, A. Fekete, K. Korany, " Application of sensory assessment, electronic tongue and GC-MS to characterize coffee samples", Arabian Journal for Science Engineering, vol 40, pp 125-133. 2015.

[30] V. Vietoris, P. Zajac, J. Capla, A. Mendelova, K. Kriznova, L. Benesova, "Comparison of coffee species by sensory panel and electronic nose", Journal of Microbiology, Biotechnology and Food Sciences, vol 5, pp 234-237. 2016

[31] M. Auda, N. Pineau, F. Mestdagh, L. Poisson, A. Rytz, "Proposal of statistical procedure to relate aroma chemistry data to aroma sensory data", in Proc AgroStat Congress. 2016.

[32] A.M. Noor Aliah, A.M. Fareez Edzuan, A.M. Noor Diana,"A Review of Quality Coffee Roasting Degree Evaluation, "Journal of Applied Science and Agriculture”, vol 10, pp 18-23. 2015.

[33] M.W. Cheong, K.H. Tong, J.J Ming Ong, S.Q Liu, P. Curran, B. Yu, "Volatile composition and antioxidant capacity of Arabica coffee", Food Research International, vol 51, pp 388-396. 2013.

[34] H.TM Tran, L.S, Lee, A. Furtado, H, Smyth, R. Henry, "Advances in genomics for improvement of quality in coffee", Science of Food and Agriculture, vol 96,pp 3300-3312.2016.

[35] Aureli, P., L. Capurso, A.M Castellazzi, M Clerici, M. Giovannini, L. Morelli, A .Poli, F. Pregliasco, F. Salvini, Zuccotti. 2011. Probiotics And Health: An Evidence-based Review. Pharmacol. res. Vol 63: 366-376.

[36] K. Sonomoto and A. Yokota, Ed., Genomics of The Genus Lactobacillus in Advanced Research. Portland, USA: Caister Academic Press, 2011.

[37] M. Fauzi. Isolasi dan karakterisasi bakteri asam laktat biji kopi Luwak (civet coffee). Jember: Universitas Jember, 2008.

[38] M.P. Chapot-Chartier and S. Kulakauskas," Cel wall structure and function in lactic acid bacteria",Microbiology Cell Fact, vol 13, pp .1475-2859. 2014.

[39] K. Todar, Lactic acid bacteria, Todar's Online Texbook of Bacteriology. 2011.

[40] L. M. Cintas, M. P. Casaus, C. Herranz, I. F. Nes and P. E. Hernández, "Review: Bacteriocins of Lactic Acid Bacteria," Food Science and Technology International, vol. 7, pp. 281-305. 2001. 